\title{
Intravenous compounding robots in pharmacy intravenous admixture services: a health technology assessment
}

lingli zhang ( $\square$ zhlingli@sina.com)

Sichuan University West China Second University Hospital

chunsong yang

Sichuan University West China Second University Hospital

Lijuan Peng

Sichuan University West China Second University Hospital

Xiaofeng Ni

Sichuan University West China Second University Hospital

\section{Research article}

Keywords: intravenous admixture medicine, intravenous compounding robot, automation, health technology assessment

Posted Date: March 2nd, 2021

DOI: https://doi.org/10.21203/rs.3.rs-279487/v1

License: (c) (i) This work is licensed under a Creative Commons Attribution 4.0 International License. Read Full License 


\section{Abstract \\ Background}

This study was performed to conduct a health technology assessment of intravenous compounding robots and provide the currently available best evidence for hospital decision-makers.

\section{Methods}

A comprehensive search of relevant professional health technology assessment websites and electronic databases (Embase, PubMed, The Cochrane Library, CNKI, VIP, CBM, and Wanfang Database) was conducted from inception to 11 August 2020. Two reviewers independently screened literature according to the inclusion and exclusion criteria and extracted data. The results were reported by qualitative description because of heterogeneity in the characteristics of the data in the included studies.

\section{Results}

Forty studies were included: 2 health technology assessments, 24 control studies ( 6 randomized controlled trials, 13 non-randomized contemporaneous controlled trials, and 6 non-randomized historical controlled trials), 12 non-controlled studies (11 single-arm studies, 1 investigation report), 1 qualitative study (in-depth interview), and 1 economics research. Effectiveness: The robots improved the production efficiency compared with usual/manual preparation; however, the intravenous preparation process requires further optimization. Additionally, robots reduced the incidence of medicine residues, preparation errors, and preparation failures. The accuracy and solution properties of intravenous admixture medicines were satisfactory, and the robots also contributed to error recognition. Safety. The robots reduced product pollution and environmental pollution, but vigilance is still required to ensure that pollution stays low. The robots also reduced the incidence of health damage to technicians. Economy. The robots reduced material costs in these studies; however, whether they can reduce labor costs remains unclear. Social suitability. Technicians had a high degree of satisfaction with the robots, but few relevant studies focused on this aspect.

\section{Conclusion}

Intravenous compounding robots have certain advantages in terms of safety, effectiveness, economy, and social adaptability. High-quality and large-sample randomized controlled trials or well-designed observational studies are still needed to evaluate such robots, especially in terms of economic and social suitability.

\section{Background}

Intravenous infusion therapy is one of the main routes of administering medication in the clinical setting. The pharmacy intravenous admixture service (PIVAS), an essential department involved in the centralized preparation and supply of intravenous admixture medicines in medical institutions, plays an important role in the quality control of intravenous admixture medicines [1]. The working mode of PIVAS is characterized by a large workload, tight timeline, multiple links, and high requirements. With the increasing demand for intravenous admixture medicines, completion of the preparation by manual labor alone will result in problems such as low efficiency, numerous errors, and high risks. One systematic review showed that the incidence of an incorrect dose, incorrect concentration, and inadequate aseptic technique in the preparation of intravenous admixture medicines in medical institutions were $32.6 \%, 88.6 \%$, and $92.7 \%$, respectively, bringing potential harm to patients [2]. A multicenter study showed that the concentration of a biomarker of DNA oxidative damage (8-hydroxy-2deoxyguanosine) was significantly higher in PIVAS staff exposed to anti-tumor drugs than in the control group, suggesting that PIVAS staff face severe health risks due to the manual preparation of anti-tumor drugs [3]. Another multicenter survey showed that PIVAS nurses were under great pressure and that the main sources of pressure were the fear of medical accidents and occupational injuries, insufficient sleep, and fatigue [4].

With the rapid development of electronic information technology, increasingly more intelligent software and equipment are being applied to PIVAS, assisting PIVAS staff in completing various tasks [5]. Automated technology is an effective way to reduce preparation errors and relieve the working pressure and occupational injuries of PIVAS staff. According to data released by the American College of Hospital Pharmacists, $0.3 \%$ of hospitals have introduced intravenous compounding robots [6]. In 2019, Amodeo et al. [7] found that the application of intravenous compounding robots increases precision, improves safety, decreases costs, and saves time, which may lead to a reduction in medication errors and improvement of patient and family care. In 2014 , Urbine et al. [8] established a pathway model based on the published literature to estimate the financial benefit of robotic preparation compared with traditional manual preparation. The results showed that the use of the robotic device prevented 5,420 medication errors and resulted in an associated savings of $\$ 288,350$ per year, showing excellent preparation accuracy and economic benefits.

However, in 2015, Nurgat et al. [9] reported that robots were used to prepare only $13.79 \%$ of anti-tumor drugs in the third year after installation, $15 \%$ of intravenous admixture medicines failed to meet the dose accuracy requirement, and robot throughput relative to the manual compounding process was low and associated with substantial medication waste. In 2013, Chen et al. [10] assessed the human resource cost after applying robot technology and found that robots were unable to improve the full-time equivalents of pharmacists/technicians, and an additional on-site engineer was even required in some cases to supervise and resolve possible machine problems. 
Before introducing medical equipment, hospitals need to perform a comprehensive evaluation and ensure that the medical equipment can benefit the patients, medical staff, and hospital. Considering the significant differences in the evaluations of intravenous compounding robots in China and abroad, it is necessary to conduct a health technology assessment (HTA) to evaluate the effectiveness, safety, economy, and social suitability of intravenous compounding robots. Therefore, based on the attention recently being given intravenous compounding robots, we performed the present HTA to evaluate the application of intravenous compounding robots and thus provide evidence for the introduction of intravenous compounding robots in PIVAS.

\section{Methods}

\section{Inclusion and exclusion criteria}

The inclusion criteria for this assessment were as follows. (1) Study types: comprehensive HTA reports, systematic reviews/meta-analyses, randomized controlled trials (RCTs), non-randomized controlled trials (NRCT), prospective/retrospective observational studies, and economic studies. (2) Study objects: Intravenous admixture medicines that were prepared in the hospital pharmacy. (3) Interventions/comparisons: An intravenous compounding robot/automatic dispensing equipment ( $A D E$ ) was applied in the intervention group, and conventional/traditional manual preparation or other types of intravenous compounding robots/ADE were applied in the control group; alternatively, the study had no control. (4) Outcomes: The effectiveness outcomes were production efficiency, medicine residues, preparation accuracy, preparation errors, preparation failures, error recognition, and solution properties. The safety outcomes were product pollution, environmental pollution, and health damage to technical personnel. The economic outcomes were labor costs and material costs. The social suitability outcome was the satisfaction of personnel.

The exclusion criteria were as follows: (1) literature without available full texts and conference abstracts; (2) news, subjective views, and editorials; and (3) repeated published literature.

\section{Search strategy}

First, we searched international (INAHTA, HTAi, ICES, ISPOR), American (AHRQ), European (EUnetHTA), British (NIHR HTA Programme), Canadian [Canadian Agency for Drugs and Technologies in Health (CADTH)], Swedish (SBU), Australian (AGDHHTA), and other professional HTA databases. Next, we searched English databases including PubMed, Embase, and The Cochrane Library and Chinese databases including China National Knowledge Infrastructure (CNKI), Wanfang Database, the Chinese Scientific Journal Database (VIP), and the Chinese Biomedical Literature Database (CBM). The English search terms were as follows: intravenous, infusion, robot, automation, intelligence, admixture, dispense, compound, preparation, and deployment. The Chinese search terms were translations and modifications of the English search terms used in the Chinese databases. Appendix 1 shows the detailed search strategy. The retrieval time was from database inception to 11 August 2020. Finally, we manually searched the references of the included studies as supplements.

\section{Literature screening and data extraction}

Two researchers independently screened the literature and extracted the data. First, the titles and abstracts of the literature were read, and then the full texts were read if they were relevant. The inclusion of all literature was decided jointly by the two researchers. In case of disagreements, the literature in question was further discussed or its inclusion/exclusion was decided by a third researcher. The data were extracted according to a predesigned data extraction table and included basic information such as the study design, sample size, intervention, effectiveness outcomes, safety outcomes, and economic outcomes. Disagreements were resolved by discussions or a decision by the third researcher. The necessary information with uncertainty was obtained by contacting the authors of the primary studies.

\section{Quality assessment of literature}

The quality of the included individual studies were assessed independently by two researchers. Currently, there is no HTA quality assessment method in the world, so HTA Checklist was used to evaluate its quality. The primary studies selected different scales (Cochrane risk of bias tool, Newcastle-Ottawa Scale, ROBINS or JBI Qualitative Assessment and Review Instrument) for quality assessment according to study types. The quality of pharmacoeconomic studies was assessed using Quality of Health Economic Studies (QHES).

\section{Data analysis}

Descriptive analysis was used because of heterogeneity in the characteristics of the data in the included studies.

\section{Results}

\section{Result of literature search}

In total, $165,52,153$, and 198 studies were obtained from CNKI, Wanfang Database, VIP, and CBM, respectively; 463, 2744, and 154 studies were obtained from PubMed, Embase, and The Cochrane Library, respectively; and 28 studies were obtained through the HTA professional websites and the references of the included studies. All studies were screened strictly in accordance with the inclusion and exclusion criteria. Finally, 40 studies [7-46] were included (2 HTAs, 26 controlled studies, 11 non-controlled studies, and 1 economic study), among which 25 studies were in foreign languages and 15 studies were in Chinese. The literature inclusion process and results are shown in Figure 1.

\section{Results of quality assessment}


The quality assessment of HTAs showed the quantity of evidence was small and the quality was low. The quality assessment of the economic study showed the the quality score (89 points) was relatively high. The description of methodology in the qualitative study was not clear and it was difficult to assess the quality. In addition, a survey report didn't have an appropriate scale for quality assessment. Details of quality assessments for other studies can be found in Appendix 2.

\section{Results of bibliometric analysis (figure 2)}

Since publication of the first study, the number of studies published in this field has increased each year. After more than 10 years of development, the application of intravenous compounding robots in China and abroad has been gradually increasing, and the number of relevant studies has reached its peak in the past three years.

\section{Results of comprehensive analysis}

\section{HTAs}

Two HTAs [11,12] were included (Table 1); both were published by the CADTH in 2013 and 2016. The results of these two HTAs showed that automation for the preparation of intravenous admixture medicines had certain security and economy. However, because the number and quality of the included original studies were low, it is necessary to update the currently available HTAs or re-evaluate the available data. International (INAHTA, HTAi, ICES, ISPOR), American (AHRQ), European (EUnetHTA), British (NIHR HTA Programme), Canadian (CADTH), Swiss (SBU), and Australian (AGDHHTA) HTA databases do not yet contain any evaluations of intravenous compounding robots.

\section{Original studies}

Thirty-eight original studies [7-10,13-46] (Table 2) were included and published from 2006 to 2020 by researchers from 11 countries, including China (16 studies, 42\%), America (6 studies, 16\%), Germany (4 studies, 11\%), France (2 studies, 5\%), Holland ( 2 studies, $5 \%$ ), Italy ( 2 studies, $5 \%$ ), and Japan ( 2 studies, $5 \%$ ). As classified by study type, these 38 studies comprised 24 controlled studies (6 RCTs, 13 contemporaneous NRCTs, and 6 historical NRCTs), 12 noncontrolled studies (11 single-arm studies, 1 investigation report), 1 qualitative study (in-depth interview), and 1 economic study. As classified by intervention type, the 38 studies comprised 26 studies that applied intravenous compounding robots and 12 studies that applied ADE (such as automated compounding devices and bidirectional precise infusion solution dispensers). Different models of automated (or robotic) equipment were applied, including the CytoCare System (Health Robotics), APOTECAchemo System (APOTECA), i.v.STATION System (Aesynt), RIVA System (Intelligent Hospital Systems), and IntelliFill i.v. System (Baxter Healthcare) as well as robots independently developed in China, such as WEINAS series robots and Angel compounding robots. The sample size of each study ranged from 10 to 11,865 , and the observation time ranged from 2 days to 3 years. The main types of intravenous admixture medicines were anti-tumor drugs (14 studies, $36 \%$ ), unclassified medicines (14 studies, $36 \%$ ), antibiotics ( 2 studies, $5 \%$ ), and total nutrient admixture ( 2 studies, $5 \%$ ).

Effectiveness: Thirty studies evaluated the effectiveness (Table 3), including 21 controlled studies and 8 non-controlled studies. The evaluation indicators were production efficiency, medicine residues, preparation accuracy, preparation errors, preparation failures, error recognition, and solution properties.

\section{Production efficiency}

Twenty-four studies [7,9,10,13-17,19-23,26,29-31,33-34,38,40-42,46] evaluated the production efficiency, including 18 controlled studies, 5 non-controlled studies, and 1 qualitative study. The data could not be merged because of the different medicine types in each study. However, 12 control studies [13-17,1922,29-31] showed that the number of preparations in the robot groups per unit time (minimum: $42.13 \pm 6.83$ bags/hour, maximum: $275 \pm 8.52$ bags/hour) was significantly higher than that in the manual group (minimum: $26.22 \pm 7.52$ bags/hour, maximum: $96.6 \pm 10.0$ bags/hour). The preparation speed of the robot group (minimum: $0.38 \pm 0.03 \mathrm{~min} / \mathrm{bag}$, maximum: $14.98 \pm 0.24 \mathrm{~min} / \mathrm{bag}$ ) was significantly higher than that of the manual group (minimum: $0.55 \pm 0.13$ $\mathrm{min} / \mathrm{bag}$, maximum: $20.21 \pm 0.68 \mathrm{~min} / \mathrm{bag}$ ). One non-controlled study [42] also showed that the robot had good production efficiency, and one in-depth interview [40] revealed that the robot improved the production efficiency by three to five times compared with the traditional manual preparation. Four studies showed that with increases in pharmacists' familiarity with robots $[10,46]$ and increases in the quantity of preparations $[7,38,46]$, the production efficiency of the robot groups was further improved. In one controlled study [23], the number of preparations by the robot reached $70.4 \%$ of the total number of preparations in the inpatient ward. Another controlled study [33] showed that an automated compounding device shortened the order-to-administration time for antibiotic first doses (from $4.5 \pm 4.1$ to $2.9 \pm 2.5$ hours, $p=0.009$ ), which was of great significance for the improvement of therapeutic effects and clinical outcomes. However, one controlled study [34] showed no significant difference in the preparation time before and after introducing the robot, and another controlled study [26] showed that the average preparation time in the robot group increased by $47 \%$ compared with that in the robot group but that the pharmacists' working time decreased by $76 \%$. Yet another controlled study [9] showed that the average number of preparations by the robot in 7 hours was comparable with that by the trained and experienced pharmacy staff in 2 to 3 hours; thus, the robot produced limited improvement in production efficiency in practice. Another non-controlled study [41] showed that although robots can significantly improve production efficiency, the manual pre-processing and post-processing steps were time-consuming and had to be reorganized.

\section{Medicine residues}

Nine studies [13-15,17,19,20,23,40,46] evaluated medicine residues, including 7 controlled studies, 1 non-controlled study, and 1 qualitative study. Six controlled studies $[13-15,17,19,23]$ conducted a quantitative analysis of medicine residues. The data could not be merged because of the different medicine types in each study, but the results of all studies showed that the rates of residues in the robot groups $(0.00 \%-4.50 \%)$ were significantly lower than those in the manual groups $(3.67 \%-50.00 \%)$. One non-controlled study [40] also showed that the use of robots reduced medicine residues, and another in-depth interview [46] showed that the robots reduced the residual amount of some insoluble medicines and alerted the technicians through an alarm when the residual amount was large. Only one controlled study [20] showed that the amount of medicine residues in the robot group (compound coenzyme: $0.11 \pm 0.01$, 
sodium carbamate: $0.12 \pm 0.01$ ) was slightly higher than that in the manual group (compound coenzyme: $0.09 \pm 0.02$, sodium carbamate: $0.08 \pm 0.02$ ); however, the amount in both groups was lower than the hospital inner quality standard.

\section{Preparation accuracy}

Ten studies $[28,9,23,7,30,44,41,38,35,46]$ evaluated the preparation accuracy, including five controlled studies, four non-controlled studies, and one qualitative study. Seven controlled studies $[28,23,9,7,30,44,41]$ conducted a quantitative analysis on the preparation accuracy (deviation of less than $\pm 5 \%$ ). The data could not be merged because of the different medicine types in each study, but the results of six studies $[28,9,7,30,44,41]$ showed that the rates of preparation accuracy in the robot groups $(0 \%-23 \%)$ were significantly higher than those in the manual groups $(5 \%-53 \%)$. One controlled study [23] showed that robotic preparations were more accurate and precise (mean absolute dose error of 0.83 for fluorouracil and 0.52 for cyclophosphamide) than manual preparations (1.20 and 1.70, respectively). In an in-depth interview [46], the vast majority of respondents indicated that compared with manual preparation, the robot improved the accuracy by adjusting the dose by itself. Two non-controlled studies $[38,35]$ showed that the preparation accuracy was related to the viscosity of the liquid and the minimum volume of the dose. The minimum volume of the non-viscous solution and viscous solution that could be accurately prepared (deviation of less than $\pm 10 \%$ ) was $2 \mathrm{ml}$ and $5 \mathrm{ml}$, respectively [38].

\section{Preparation errors}

Eleven studies [13-15,17,19,26,31,32,37,40,46] evaluated the incidence of preparation errors, including eight controlled studies, two non-controlled studies, and one qualitative study. Seven controlled studies [13-15,17,19,26,31] conducted a quantitative analysis on the incidence of preparation errors in the robot groups and manual groups. The data could not be merged because of the different medicine types in each study, but the results of all studies showed that the incidence of preparation errors in the robot groups ranged from $0.0 \%$ to $0.9 \%$, which was significantly lower than that in the manual group (0.013\%- $12.5 \%)$ $[13-15,17,19,26,31]$. One study showed that the number of daily preparation errors was reduced from $0.26 \pm 0.78$ to $0.06 \pm 0.13$ [32]. One non-controlled study [40] and one in-depth interview [46] also showed that the robots could reduce the incidence of preparation errors by warning, without interference by factors such as visual fatigue. Finally, a 3 -year real-world study [37] showed that the percentage of actual failed preparations was $<1 \%(0.21 \%, 0.15 \%$, and $0.18 \%$ in 2015, 2016, and 2017, respectively).

\section{Preparation failures}

Three studies $[9,10,42]$ evaluated the incidence of preparation failures, including one controlled study and two non-controlled studies. The model used in two of the studies was the CytoCare, and the incidence of failures was $12 \%(n=1028)[10]$ and $19 \%(n=4509)$ [9], respectively. The model used in another study was the APOTECAChemo, and the incidence of failures was $2 \%(n=11,642)$ [42]. The reasons for preparation failures included robot shutdowns, mechanical failures, re-calibration, and other practical problems [9]. However, as the application time increases, the rate of preparation success might gradually improve. For example, one study [10] showed that the rate of preparation success increased from $76.8 \%$ in week 1 to $95.3 \%$ in week 10 .

\section{Solution properties}

Two RCTs [22,25] evaluated the properties of the solutions prepared by the robots. In one study [22], measurement of the size, $\mathrm{pH}$ value, and osmotic concentration of lipid particles in the nutrient solutions showed that the nutrient solutions prepared by the automated compounding device were superior to those prepared by gravity infusion in terms of stability and compatibility. By measuring antibody aggregation, another study [25] concluded that robotic compounding of monoclonal antibodies was feasible and that the robot could be used to achieve reproducible high-quality compounding for delicate formulations.

\section{Error recognition}

One non-controlled study [42] evaluated the robots' role in error recognition. The study showed that the robot recognized $1.12 \%(n=133)$ of errors that would have caused harm to patients.

Safety: Twenty-two studies evaluated safety (Table 3), including 13 controlled studies, 8 non-controlled studies, and 1 qualitative study. The evaluation indicators were product pollution, environmental pollution, and health damage to technical personnel.

\section{Product pollution}

Eleven studies $[27,21,39,30,45,43,41,38,36,35,46]$ evaluated product pollution, including three controlled studies, seven non-controlled studies, and one qualitative study. Five studies $[39,30,41,38,36,35]$ did not detect microbial pollution, and one non-controlled study [43] showed that non-contaminated bags were not contaminated after preparation, revealing that the robot enabled the preparations with low levels of product contamination. One controlled study [21] showed that the positive rate of bacterial cultures in the piston decreased from $26.67 \%$ to $13.33 \%$, revealing that the robot could significantly reduce the possibility of product pollution. One in-depth interview [46] revealed that the robot was cleaner than the biological safety cabinet because it had an air channel cleaning system and a closed negative-pressure environment. However, another study [27] showed that the microbial culture positive rate was $7.9 \%(n=152)$, which was related to product pollution. Another investigation showed that microbial contamination might originate from the washing station, which was easily be ignored [45]. Finally, the technicians' gloves were also key sites of microbial contamination [35].

\section{Environmental pollution}

Eight studies $[24,23,39,18,43,38,36,35]$ evaluated environmental pollution, including three controlled studies and five non-controlled studies. Two controlled studies $[24,18]$ showed that the external pollution of the robots was relatively low through monitoring gloves, infusion bags, and other equipment, indicating 
that environmental pollution could be improved. One non-controlled study [38] detected only one type of contamination associated with pulling the needle out of the syringe, which was very small (spots of $<3 \mathrm{~mm}$ ) but relatively frequent (11\%). Pollution was mainly observed inside the robot [43], especially in the area of the dosing device $[24,23,39]$. The robot was able to perform automatic microbial decontamination by ultraviolet radiation [36]. One controlled study and one non-controlled study showed that the settling plate/contact plate met the recommended limits for the class A area of the clean room [39] and that the surface and air samples complied with an ISO 5 class environment [35], indicating that the robots had well-controlled programs.

\section{Health damage}

Eleven studies $[26,17,23,15,16,14,13,19,43,40,46]$ assessed health damage to the technical personnel, including eight controlled studies, two non-controlled studies, and one qualitative study. Seven controlled studies $[26,17,15,16,14,13,19]$ performed a quantitative analysis of the incidence of health damage to technical personnel in both the robot groups (chapped fingers: $n=0$, ampoule scratches: $n=0$, fatigue: $n=0-1$, syringe stabs: $n=0-3$ ) and manual groups (chapped fingers: $n=1-29$, ampoule scratches: $n=2-38$, fatigue: $n=3-19$, syringe stabs: $n=1-28$ ). The results showed that the incidence of health damage to technical personnel was significantly lower in the robot groups $(0.0 \%-2.9 \%)$ than in the manual groups $(5.1 \%-40.0 \%)$, and the somatic pain score was also significantly lower in the robot groups than manual groups ( $2.65 \pm 0.47$ vs. $5.76 \pm 0.03$, respectively). One non-controlled study [40] also showed that the robot could provide effective occupational protection for nurses. In an in-depth interview [46], all interviewees were nurses in the oncology ward and daytime chemotherapy center, and they had strong experience with occupational protection provided by the robots. Two studies $[23,43]$ showed that no contaminant exposure was found in the gloves or on the hands of the technicians by applying the robots.

Economy: Six studies $[34,26,10,7,30,8]$ conducted an economic evaluation, including four controlled studies, one non-controlled study, and one economic study. The evaluation indicators were labor costs and material costs. Through 1000 simulations, an economic study [8] showed that robots could reduce healthcare costs by preventing medication errors and reducing adverse drug events, saving an average of $\$ 288,350$ per year. Three controlled studies [26,7,30]

showed that robots could reduce costs by $8 \%$ to $66 \%$ by saving materials, and the cost savings might continue to rise with the increase in preparations [7]. One controlled study [34] showed that a robot could reduce the labor costs of three pharmacists, but two other studies [26,10] showed that the robots could not reduce labor costs, could not improve the full-time equivalent of a hospital general pharmacist/technician, and even needed additional on-site engineers to help resolve possible breakdown.

Social suitability: Only one study [37] investigated technicians' satisfaction with robots. The results showed that responders agreed that the overall impression of robots was "very good," and the safety features of robots had a median score of being "very safe".

\section{Discussion}

\section{Findings and clinical value of this study}

Based on the currently available evidence, robots can improve production efficiency over the usual manual preparation, but the intravenous preparation process still requires further optimization. Robots can also reduce the incidence of medicine residues, preparation errors, and preparation failures. The studies evaluated herein showed that the accuracy and solution properties of intravenous admixture medicines were satisfactory and that robots had a role in error recognition. With respect to safety, robots can reduce product pollution and environmental pollution; however, vigilance is still required to ensure that pollution stays low. Additionally, robots can reduce the incidence of health damages to technicians. With respect to economic factors, robots can reduce material costs, but whether they can reduce labor costs remains to be further studied. Finally, in terms of social suitability, technicians had a high degree of satisfaction with the robots. However, there are relatively few relevant studies on this aspect at present.

Only two HTAs of intravenous compounding robots have been performed to date, and the number and quality of the original studies included are low. Therefore, in the present study, we re-evaluated intravenous compounding robots. We included the original studies in all respects and selected evaluation indicators covering various aspects to comprehensively analyze the effectiveness, safety, economy, and social suitability of intravenous compounding robots, providing a reference for future introduction and application of intravenous compounding robots in medical institutions.

\section{Limitations of this study}

This study has three main limitations. First, because of our limited access to data, we were unable to obtain the full texts of some studies that met the inclusion criteria, and only studies from which we could extract data were included. This might have introduced a risk of bias that affected the conclusion. Second, the original studies differed in terms of the robot models, types of intravenous admixture medicines, and technical personnel's familiarity with robots. There was great heterogeneity among the studies, preventing the data from being merged; thus, only qualitative analyses could be conducted. Third, most of the original studies involved evaluations of effectiveness and safety and lacked evidence of economy and social adaptability. This made it impossible to carry out a more comprehensive HTA for intravenous compounding robots.

\section{Future research directions}

This analysis showed that most of the currently available studies of intravenous compounding robots have a high risk of bias and small sample size. Therefore, high-quality, large-scale, multicenter RCTs or well-designed observational studies are needed for further evaluation. Additionally, only five studies in this analysis included economic evaluations, and only one study included a social suitability evaluation. More attention should be paid to the economy and social suitability of intravenous compounding robots in future studies to provide more evidence for medical institutions. In addition, PIVAS in medical institutions should cooperate with the manufacturers of intravenous compounding robots to jointly determine how to further optimize intravenous compounding robots, reduce preparation errors and safety events, and improve the service quality of intravenous compounding robots. 


\section{Conclusion}

Intravenous compounding robots have certain advantages in terms of safety, effectiveness, economy, and social adaptability. High-quality and large-sample RCTs or well-designed observational studies are still needed to further evaluate these robots, especially in terms of economic and social suitability.

\section{Abbreviations}

RCT: Randomized Controlled Trial; PIVAS: Pharmacy Intravenous Admixture Service; HTA: Health Technology Assessment; NRCT: Non-Randomized Controlled Trials; ADE: Automatic Dispensing Equipment.

\section{Declarations}

Acknowledgment: We thank Angela Morben, DVM, ELS, from Liwen Bianji, Edanz Editing China (www.liwenbianji.cn/ac), for editing the English text of a draft of this manuscript.

Ethics approval and consent to participate: As this study does not involve human or animal experiments, this section is not applicable.

Consent for publication: As this manuscript contains no individual personal data, this section is not applicable.

Availability of data and materials: The datasets generated and/or analyzed during the current study are not publicly available because they are subject to the West China Second University Hospital, Sichuan University. However, the data and materials are available from the corresponding author on reasonable request.

Competing interests: The authors declared that they had no competing interests.

Funding: This study was funded by National Health and Wellness Committee:

health technology assessment of Intravenous compounding robots (00402154A8002). The sponsor had no role in the study design, writing of the manuscript, or decision to submit this or future manuscripts for publication.

Authors' contributions: CS Yang and XF Ni contributed equally to this study. CS Yang and XF Ni: designed the study, collected data, carried out analysis and interpretation of the data and wrote the study. LJ Peng: designed the review, collected data, checked the data and wrote the study. LL Zhang: designed the review, commented on drafts for previous version.

\section{References}

Citation list not provided with this version

\section{Tables}

Table 1 Basic information, evidence and results of included HTAs

\begin{tabular}{|c|c|c|c|c|c|c|c|}
\hline HTAs & Country & $\begin{array}{l}\text { Number } \\
\text { of } \\
\text { included } \\
\text { studies }\end{array}$ & $\begin{array}{l}\text { Intervention } \\
\text { group }\end{array}$ & Control group & Clinical evidence & Economic evidence & Conclusion \\
\hline $\begin{array}{l}\text { CADTH } \\
2013^{[11]}\end{array}$ & Canada & 2 & $\begin{array}{l}\text { Automated } \\
\text { (or robotic) } \\
\text { equipment }\end{array}$ & $\begin{array}{l}\text { Manual } \\
\text { method }\end{array}$ & $\begin{array}{l}\text { Two non- } \\
\text { randomized studies } \\
\text { were identified } \\
\text { regarding the safety } \\
\text { for patients in acute } \\
\text { care. }\end{array}$ & No literature identified & $\begin{array}{l}\text { Automation for the } \\
\text { preparation of intravenous } \\
\text { solutions has certain security }\end{array}$ \\
\hline $\begin{array}{l}\text { CADTH } \\
2016^{[12]}\end{array}$ & Canada & 2 & $\begin{array}{l}\text { Automated } \\
\text { (or robotic) } \\
\text { equipment }\end{array}$ & $\begin{array}{l}\text { Manual or } \\
\text { alternate } \\
\text { methods, or } \\
\text { no } \\
\text { comparator }\end{array}$ & $\begin{array}{l}\text { One non- } \\
\text { randomized study } \\
\text { was identified } \\
\text { regarding the safety } \\
\text { for patients in acute } \\
\text { care. }\end{array}$ & $\begin{array}{l}\text { One economic evaluation } \\
\text { was identified regarding the } \\
\text { economy for patients in } \\
\text { acute care. }\end{array}$ & $\begin{array}{l}\text { Automation for the } \\
\text { preparation of intravenous } \\
\text { solutions has certain security } \\
\text { and economy }\end{array}$ \\
\hline
\end{tabular}

Table 2 Basic Information of Included Studies 


\begin{tabular}{|c|c|c|c|c|c|c|c|c|}
\hline $\begin{array}{l}\text { Included } \\
\text { Studies }\end{array}$ & Country & Study Type & Robot Model & $\begin{array}{l}\text { Observation } \\
\text { group }\end{array}$ & $\begin{array}{l}\text { Control } \\
\text { Group }\end{array}$ & $\begin{array}{l}\text { Sample Size } \\
\text { (Observation } \\
\text { Group/Control } \\
\text { Group) }\end{array}$ & $\begin{array}{l}\text { Observation } \\
\text { Time }\end{array}$ & $\begin{array}{l}\text { Types of Intra' } \\
\text { Medicines }\end{array}$ \\
\hline \multicolumn{9}{|c|}{ Controlled study } \\
\hline $\begin{array}{l}\text { Wang YJ } \\
2020[13]\end{array}$ & China & RCT & NR & Robot & $\begin{array}{l}\text { Manual } \\
\text { preparation }\end{array}$ & $480 / 480$ & I & Unclassified $n$ \\
\hline $\begin{array}{l}\text { Cheng XL } \\
\text { 2019[14] }\end{array}$ & China & $\mathrm{RCT}$ & NR & Robot & $\begin{array}{l}\text { Manual } \\
\text { preparation }\end{array}$ & $300 / 300$ & / & Unclassified $\mathrm{r}$ \\
\hline $\begin{array}{l}\operatorname{Jin} Z \text { Z } \\
2018[15]\end{array}$ & China & $\mathrm{RCT}$ & NR & Robot & $\begin{array}{l}\text { Manual } \\
\text { preparation }\end{array}$ & $200 / 200$ & / & Unclassified $\mathrm{n}$ \\
\hline $\begin{array}{l}\text { Wang JM } \\
2018[16]\end{array}$ & China & $\mathrm{RCT}$ & $\begin{array}{l}\text { STD-TV Intelligent } \\
\text { Dispenser }\end{array}$ & $\mathrm{ADE}$ & $\begin{array}{l}\text { Manual } \\
\text { preparation }\end{array}$ & $750 / 750$ & / & Other(Kangai i \\
\hline $\begin{array}{l}\text { Zhou HZ } \\
\text { 2017[17] }\end{array}$ & China & $\mathrm{RCT}$ & WEINAS-PD160 & Robot & $\begin{array}{l}\text { Manual } \\
\text { preparation }\end{array}$ & $200 / 200$ & / & Unclassified $\mathrm{n}$ \\
\hline $\begin{array}{l}\text { Werumeus } \\
\text { Buning } \\
2020[18]\end{array}$ & Holland & $\begin{array}{l}\text { NRCT } \\
\text { (Contemporaneous) }\end{array}$ & APOTECAchemo & Robot & $\begin{array}{l}\text { Manual } \\
\text { preparation }\end{array}$ & $80 / 80$ & / & $\begin{array}{l}\text { Anti-tumor dru } \\
\text { fluorouracil, } \\
\text { cyclophospha }\end{array}$ \\
\hline $\begin{array}{l}\text { Yang P } \\
2020[19]\end{array}$ & China & $\begin{array}{l}\text { NRCT } \\
\text { (Contemporaneous) }\end{array}$ & $\mathrm{P}-006-\mathrm{C} \otimes, \mathrm{p}-006-\mathrm{z} \nabla$ & Robot & $\begin{array}{l}\text { Manual } \\
\text { preparation }\end{array}$ & $500 / 500$ & I & Unclassified $\mathrm{n}$ \\
\hline $\begin{array}{l}\text { Shen GR } \\
\text { 2020[20] }\end{array}$ & China & $\begin{array}{l}\text { NRCT } \\
\text { (Contemporaneous) }\end{array}$ & AMSII & $\mathrm{ADE}$ & $\begin{array}{l}\text { Manual } \\
\text { preparation }\end{array}$ & $600 / 600$ & / & $\begin{array}{l}\text { Other(comple> } \\
\text { coenzyme, so } \\
\text { carbosulfonat }\end{array}$ \\
\hline $\begin{array}{l}\mathrm{Hu} \mathrm{L} \\
2016[21]\end{array}$ & China & $\begin{array}{l}\text { NRCT } \\
\text { (Contemporaneous) }\end{array}$ & NR & $\mathrm{ADE}$ & $\begin{array}{l}\text { Manual } \\
\text { preparation }\end{array}$ & $15 / 15$ & / & $\begin{array}{l}\text { Other (reducec } \\
\text { glutathione) }\end{array}$ \\
\hline $\begin{array}{l}\text { Yang J } \\
2006[22]\end{array}$ & China & $\begin{array}{l}\text { NRCT } \\
\text { (Contemporaneous) }\end{array}$ & Automix $3+3$ (Baxter) & $\mathrm{ADE}$ & $\begin{array}{l}\text { Manual } \\
\text { preparation }\end{array}$ & $10 / 10$ & / & TNA \\
\hline $\begin{array}{l}\text { Amodeo } \\
2019[7]\end{array}$ & Italy & $\begin{array}{l}\text { NRCT } \\
\text { (Contemporaneous) }\end{array}$ & i.v.Station & Robot & $\begin{array}{l}\text { Manual } \\
\text { preparation }\end{array}$ & $100 / 100$ & / & $\begin{array}{l}\text { Unclassified n } \\
\text { (Neonatal Inte } \\
\text { Unit) }\end{array}$ \\
\hline $\begin{array}{l}\text { Iwamoto } \\
2017[23]\end{array}$ & Japan & $\begin{array}{l}\text { NRCT } \\
\text { (Contemporaneous) }\end{array}$ & APOTECAchemo & Robot & $\begin{array}{l}\text { Manual } \\
\text { preparation }\end{array}$ & $40 / 40$ & / & $\begin{array}{l}\text { Anti-tumor dru } \\
\text { (fluorouracil, } \\
\text { cyclophospha }\end{array}$ \\
\hline $\begin{array}{l}\text { Nurgat } \\
2015[9]\end{array}$ & $\begin{array}{l}\text { Saudi } \\
\text { Arabia }\end{array}$ & $\begin{array}{l}\text { NRCT } \\
\text { (Contemporaneous) }\end{array}$ & CytoCare & Robot & $\begin{array}{l}\text { Manual } \\
\text { preparation }\end{array}$ & $3679 / 134$ & / & Anti-tumor dru \\
\hline $\begin{array}{l}\text { Schierl } \\
2014[24]\end{array}$ & Germany & $\begin{array}{l}\text { NRCT } \\
\text { (Contemporaneous) }\end{array}$ & APOTECAchemo & Robot & $\begin{array}{l}\text { Manual } \\
\text { preparation }\end{array}$ & $50 / 49$ & / & $\begin{array}{l}\text { Anti-tumor dru } \\
\text { (cyclophosphá }\end{array}$ \\
\hline $\begin{array}{l}\text { Peters } \\
2013[25]\end{array}$ & Holland & $\begin{array}{l}\text { NRCT } \\
\text { (Contemporaneous) }\end{array}$ & i.v.STATION & Robot & $\begin{array}{l}\text { Manual } \\
\text { preparation }\end{array}$ & $8 / 6$ & l & $\begin{array}{l}\text { Anti-tumor dru } \\
\text { (Infliximab, } \\
\text { Trastuzumab, } \\
\text { bevacizumab) }\end{array}$ \\
\hline $\begin{array}{l}\text { Seger } \\
2012[26]\end{array}$ & America & $\begin{array}{l}\text { NRCT } \\
\text { (Contemporaneous) }\end{array}$ & CytoCare & Robot & $\begin{array}{l}\text { Manual } \\
\text { preparation }\end{array}$ & $972 / 1421$ & / & Anti-tumor dru \\
\hline $\begin{array}{l}\text { Ybarra } \\
2010[27]\end{array}$ & America & $\begin{array}{l}\text { NRCT } \\
\text { (Contemporaneous) }\end{array}$ & NR & $\mathrm{ADE}$ & $\begin{array}{l}\text { Commercially } \\
\text { available } \\
\text { preparations }\end{array}$ & $152 / 40$ & / & $\begin{array}{l}\text { TNA(Lipid emı } \\
\text { children) }\end{array}$ \\
\hline $\begin{array}{l}\text { Dehmel } \\
2011[28]\end{array}$ & Germany & $\begin{array}{l}\text { NRCT } \\
\text { (Contemporaneous) }\end{array}$ & NR & $\mathrm{ADE}$ & $\begin{array}{l}\text { Manual } \\
\text { preparation }\end{array}$ & $100 / 100$ & / & $\begin{array}{l}\text { Other (Amioda } \\
\text { norepinephrinı } \\
\text { hydrocortisonı }\end{array}$ \\
\hline $\begin{array}{l}\text { Li XY } \\
\text { 2019[29] }\end{array}$ & China & NRCT (Historical) & REPEATER Pump & $\mathrm{ADE}$ & $\begin{array}{l}\text { Manual } \\
\text { preparation }\end{array}$ & / & 3 months & Unclassified $n$ \\
\hline $\begin{array}{l}\mathrm{LiY} \\
\text { 2019[30] }\end{array}$ & China & NRCT (Historical) & C.A.S IMK SDP-3AD & $\mathrm{ADE}$ & $\begin{array}{l}\text { Manual } \\
\text { preparation }\end{array}$ & / & 4 months & $\begin{array}{l}\text { Antibiotics(Ce } \\
\text { sulbactam sor }\end{array}$ \\
\hline $\begin{array}{l}\text { Song L } \\
2019[31]\end{array}$ & China & NRCT (Historical) & NR & $\mathrm{ADE}$ & $\begin{array}{l}\text { Manual } \\
\text { preparation }\end{array}$ & / & 6 months & Unclassified $\mathrm{n}$ \\
\hline $\begin{array}{l}\text { Shen GR } \\
\text { 2017[32] }\end{array}$ & China & NRCT (Historical) & NR & $\mathrm{ADE}$ & $\begin{array}{l}\text { Manual } \\
\text { preparation }\end{array}$ & / & 3 months & Unclassified $\mathrm{n}$ \\
\hline $\begin{array}{l}\text { Lo } \\
2014[33]\end{array}$ & America & NRCT (Historical) & NR & $\mathrm{ADE}$ & $\begin{array}{l}\text { Manual } \\
\text { preparation }\end{array}$ & $56 / 65$ & / & $\begin{array}{l}\text { Antibiotics (Pi } \\
\text { Tazobactam) }\end{array}$ \\
\hline $\begin{array}{l}\text { Ishimoto } \\
2011[34]\end{array}$ & Japan & NRCT (Historical) & YS-APD- $100 / A P S$ & $\mathrm{ADE}$ & $\begin{array}{l}\text { Manual } \\
\text { preparation }\end{array}$ & / & 1.5 months & Unclassified $n$ \\
\hline
\end{tabular}




\begin{tabular}{|c|c|c|c|c|c|c|c|c|}
\hline $\begin{array}{l}\text { Jobard } \\
2020[35]\end{array}$ & France & Single-arm study & KIRO Oncology & Robot & - & 274 & / & Placebo soluti \\
\hline $\begin{array}{l}\text { Sabatini } \\
2019[36]\end{array}$ & Italy & Single-arm study & APOTECAunit & Robot & - & / & 2 months & Unclassified n \\
\hline $\begin{array}{l}\text { Nurgat } \\
2019[37]\end{array}$ & Canada & Single-arm study & RIVA & Robot & - & / & 36 months & $\begin{array}{l}\text { Unclassified } n \\
\text { (Small volum } € \\
\text { preparation) }\end{array}$ \\
\hline $\begin{array}{l}\text { Carrez } \\
2018[38]\end{array}$ & Switzerland & Single-arm study & PharmaHelp & Robot & - & 150 & I & $\begin{array}{l}\text { Anti-tumor dru } \\
\text { (Cytotoxic dru }\end{array}$ \\
\hline $\begin{array}{l}\text { Krämer } \\
2018[39]\end{array}$ & Germany & Single-arm study & APOTECAchemo & Robot & - & 50 & / & Other (Gancicl \\
\hline $\begin{array}{l}\text { Zhao Y } \\
2018[40]\end{array}$ & China & Single-arm study & $\begin{array}{l}\text { Angel compounding } \\
\text { robots }\end{array}$ & Robot & - & 115 & 12 months & Anti-tumor dru \\
\hline $\begin{array}{l}\text { Chen } \\
\text { 2013[10] }\end{array}$ & China & Single-arm study & CytoCare & Robot & - & 1028 & 2 months & Anti-tumor dru \\
\hline $\begin{array}{l}\text { Schoening } \\
\text { 2016[41] }\end{array}$ & Germany & Single-arm study & PharmaHelp & Robot & - & / & 6 months & Anti-tumor dru \\
\hline $\begin{array}{l}\text { De La } \\
\text { Ramos } \\
\text { 2015[42] }\end{array}$ & France & Single-arm study & APOTECAChemo & Robot & - & 11865 & 31 months & Anti-tumor dru \\
\hline $\begin{array}{l}\text { Sessink } \\
2014[43]\end{array}$ & Belgium & Single-arm study & CytoCare & Robot & - & / & 2 days & Anti-tumor dru \\
\hline $\begin{array}{l}\text { Yaniv } \\
\text { 2013[44] }\end{array}$ & America & Single-arm study & APOTECAchemo & Robot & - & 7384 & 13 months & Anti-tumor dru \\
\hline $\begin{array}{l}\text { Cluck } \\
2012[45]\end{array}$ & America & Investigation report & Intellifill i.v. & Robot & & / & / & Unclassified $n$ \\
\hline \multicolumn{9}{|c|}{ Qualitative Study } \\
\hline $\begin{array}{l}\text { Wang T } \\
2019[46]\end{array}$ & China & In-depth interview & NR & Robot & & 10 & / & Anti-tumor dru \\
\hline \multicolumn{9}{|c|}{ Economic Study } \\
\hline $\begin{array}{l}\text { Urbine } \\
2014[8]\end{array}$ & America & Economic study & RIVA & Robot & $\begin{array}{l}\text { Manual } \\
\text { preparation }\end{array}$ & $\begin{array}{l}1000 \text { times } \\
\text { simulations }\end{array}$ & l & Unclassified $n$ \\
\hline
\end{tabular}

Abbreviations: RCT: Randomized controlled trial,NRCT: Non-Randomized controlled trial, ADE:Automatic dispensing equipment, TNA: Total nutrient admixture 


\begin{tabular}{|c|c|c|c|c|c|c|c|c|}
\hline \multirow[t]{2}{*}{ Study } & \multicolumn{2}{|c|}{ Effectiveness } & \multicolumn{2}{|l|}{ Safety } & \multicolumn{2}{|l|}{ Economy } & \multicolumn{2}{|c|}{ Social suitability } \\
\hline & Outcomes & Conclusions & Outcomes & Conclusions & Outcomes & Conclusions & Outcomes & Conclusions \\
\hline \multicolumn{9}{|c|}{ Controlled studies } \\
\hline $\begin{array}{l}\text { Wang YJ } \\
2020[13]\end{array}$ & 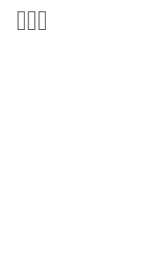 & $\begin{array}{l}\text { The robot could } \\
\text { significantly } \\
\text { improve the } \\
\text { dispensing } \\
\text { efficiency, and } \\
\text { reduce the rate of } \\
\text { dispensing errors } \\
\text { and medicine } \\
\text { residues. }\end{array}$ & $\square$ & $\begin{array}{l}\text { The robot could } \\
\text { reduce the } \\
\text { accidents of } \\
\text { injury, playing a } \\
\text { protective role for } \\
\text { the nurse's health. }\end{array}$ & - & - & - & - \\
\hline $\begin{array}{l}\text { Cheng XL } \\
\text { 2019[14] }\end{array}$ & प्रा & $\begin{array}{l}\text { The robot } \\
\text { guaranteed the } \\
\text { accuracy and } \\
\text { safety of infusion, } \\
\text { and reduced the } \\
\text { error rate of } \\
\text { disposition. }\end{array}$ & 口 & $\begin{array}{l}\text { The robot was } \\
\text { beneficial to } \\
\text { strengthen the } \\
\text { occupational } \\
\text { protection of } \\
\text { personnel. }\end{array}$ & - & - & - & - \\
\hline $\begin{array}{l}\text { Jin Z } \\
2018[15]\end{array}$ & 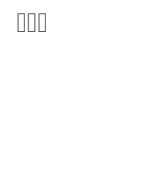 & $\begin{array}{l}\text { Robots could } \\
\text { effectively ensure } \\
\text { the safety and } \\
\text { accuracy of } \\
\text { infusion, avoiding } \\
\text { deployment errors. }\end{array}$ & प & $\begin{array}{l}\text { Robots could } \\
\text { reduce the harm } \\
\text { of dispensation to } \\
\text { nurses. }\end{array}$ & - & - & - & - \\
\hline $\begin{array}{l}\text { Wang JM } \\
\text { 2018[16] }\end{array}$ & 口 & $\begin{array}{l}\text { The speed of } \\
\text { dispensing had } \\
\text { been significantly } \\
\text { improved because } \\
\text { of the automated } \\
\text { compounding } \\
\text { device. }\end{array}$ & प & $\begin{array}{l}\text { Physical pain was } \\
\text { significantly } \\
\text { reduced because } \\
\text { of the automated } \\
\text { compounding } \\
\text { device. }\end{array}$ & - & - & - & - \\
\hline $\begin{array}{l}\text { Zhou HZ } \\
2017[17]\end{array}$ & $\mathrm{Qस्र}$ & $\begin{array}{l}\text { Robots could } \\
\text { improve the } \\
\text { efficiency, reduce } \\
\text { medicine residues } \\
\text { and dispensing } \\
\text { errors, and } \\
\text { increase the } \\
\text { accuracy of } \\
\text { dispensation. }\end{array}$ & प & $\begin{array}{l}\text { Nurses' } \\
\text { occupational } \\
\text { injury caused by } \\
\text { dispensing was } \\
\text { reduced. }\end{array}$ & - & - & - & - \\
\hline $\begin{array}{l}\text { Werumeus } \\
\text { Buning } \\
2020[18]\end{array}$ & - & - & प & $\begin{array}{l}\text { External (cross-) } \\
\text { contamination of } \\
\text { infusion bags was } \\
\text { lower using the } \\
\text { robotic system. }\end{array}$ & - & - & - & - \\
\hline $\begin{array}{l}\text { Yang P } \\
2020[19]\end{array}$ & प्रा & $\begin{array}{l}\text { The robot has } \\
\text { higher accuracy } \\
\text { and safety, and it } \\
\text { could effectively } \\
\text { dispense } \\
\text { intravenous } \\
\text { medicines and } \\
\text { reduce the rate of } \\
\text { errors. }\end{array}$ & प & $\begin{array}{l}\text { The robot could } \\
\text { prevent } \\
\text { unnecessary } \\
\text { injury to the } \\
\text { nurses. }\end{array}$ & - & - & - & - \\
\hline $\begin{array}{l}\text { Shen GR } \\
2020[20]\end{array}$ & प्र & $\begin{array}{l}\text { Automatic } \\
\text { compounding } \\
\text { system could } \\
\text { improve the } \\
\text { working efficiency, } \\
\text { and reduce the } \\
\text { workload of staff. } \\
\text { Although the } \\
\text { medicine residues } \\
\text { was slightly higher, } \\
\text { it still met the } \\
\text { internal standard. }\end{array}$ & - & - & - & - & - & - \\
\hline $\begin{array}{l}\mathrm{Hu} \mathrm{L} \\
2016[21]\end{array}$ & $\square$ & $\begin{array}{l}\text { The automated } \\
\text { compounding } \\
\text { device could save } \\
\text { time. }\end{array}$ & प & $\begin{array}{l}\text { The automated } \\
\text { compounding } \\
\text { device could } \\
\text { reduced pollution } \\
\text { of liquids }\end{array}$ & - & - & - & - \\
\hline $\begin{array}{l}\text { Yang J } \\
2006[22]\end{array}$ & $\mathrm{Qu}$ & $\begin{array}{l}\text { The automated } \\
\text { compounding } \\
\text { device was more } \\
\text { time saving, better }\end{array}$ & - & - & - & - & - & - \\
\hline
\end{tabular}

Page 10/15 
stability and

compatibility.

\begin{tabular}{|c|c|c|c|c|c|c|c|c|}
\hline $\begin{array}{l}\text { Amodeo } \\
2019[7]\end{array}$ & प्र & $\begin{array}{l}\text { The benefits of } \\
\text { robot included } \\
\text { increased } \\
\text { precision in drug } \\
\text { preparation, } \\
\text { improved safety, } \\
\text { and saved time. }\end{array}$ & - & - & प्रा & $\begin{array}{l}\text { The benefits of robot } \\
\text { included improved } \\
\text { safety. }\end{array}$ & - & - \\
\hline $\begin{array}{l}\text { Iwamoto } \\
2017 \text { [23] }\end{array}$ & प्रा & $\begin{array}{l}\text { Robotic } \\
\text { preparation had } \\
\text { substantial } \\
\text { advantages in } \\
\text { drug compounding } \\
\text { for accuracy. }\end{array}$ & प्र & $\begin{array}{l}\text { Robotic } \\
\text { preparation had } \\
\text { substantial } \\
\text { advantages in } \\
\text { drug } \\
\text { compounding for } \\
\text { safety. }\end{array}$ & - & - & - & - \\
\hline $\begin{array}{l}\text { Nurgat } \\
2015[9]\end{array}$ & प्रा & $\begin{array}{l}\text { Robots for } \\
\text { preparation had a } \\
\text { limited efficiency } \\
\text { impact in practice. } \\
\text { This solution was } \\
\text { not yet mature } \\
\text { enough for } \\
\text { universal adoption. }\end{array}$ & - & - & - & - & - & - \\
\hline $\begin{array}{l}\text { Schierl } \\
2014[24]\end{array}$ & - & - & ૫ & $\begin{array}{l}\text { Contamination } \\
\text { was lower when } \\
\text { the production } \\
\text { was carried out by } \\
\text { the robot. }\end{array}$ & - & - & - & - \\
\hline $\begin{array}{l}\text { Peters } \\
2013[25]\end{array}$ & प & $\begin{array}{l}\text { Robotic } \\
\text { compounding of } \\
\text { mAbs is feasible, } \\
\text { indicating it can be } \\
\text { used to achieve } \\
\text { reproducible high- } \\
\text { quality } \\
\text { compounding for } \\
\text { delicate } \\
\text { formulations. }\end{array}$ & - & - & - & - & - & - \\
\hline $\begin{array}{l}\text { Seger } \\
2012[26]\end{array}$ & प्रा & $\begin{array}{l}\text { Although the robot } \\
\text { did not reduce } \\
\text { serious medication } \\
\text { errors, accuracy of } \\
\text { medication } \\
\text { preparation was } \\
\text { improved } \\
\text { signifificantly. }\end{array}$ & प & $\begin{array}{l}\text { Staff safety was } \\
\text { improved } \\
\text { signifificantly by } \\
\text { robotically } \\
\text { preparing. }\end{array}$ & प्र & $\begin{array}{l}\text { Labor costs were similar, } \\
\text { although the ancillary } \\
\text { material costs decreased. }\end{array}$ & - & - \\
\hline $\begin{array}{l}\text { Ybarra } \\
2010[27]\end{array}$ & - & - & 口 & $\begin{array}{l}\text { The positive } \\
\text { microbial growth } \\
\text { related with the } \\
\text { automated } \\
\text { compounding } \\
\text { device. }\end{array}$ & - & - & - & - \\
\hline $\begin{array}{l}\text { Dehmel } \\
2011[28]\end{array}$ & प & $\begin{array}{l}\text { Centralised, } \\
\text { automated } \\
\text { preparation of } \\
\text { standardised } \\
\text { infusion solutions } \\
\text { may be an } \\
\text { effective means to } \\
\text { reduce this type of } \\
\text { medication error. }\end{array}$ & - & - & - & - & - & - \\
\hline $\begin{array}{l}\text { Li XY } \\
2019[29]\end{array}$ & प & $\begin{array}{l}\text { Automatic system } \\
\text { improved the work } \\
\text { efficiency and } \\
\text { reduce the labor } \\
\text { intensity of the } \\
\text { staff. }\end{array}$ & - & - & - & - & - & - \\
\hline $\begin{array}{l}\mathrm{LiYY} \\
2019[30]\end{array}$ & प्र & $\begin{array}{l}\text { The dispenser } \\
\text { could improve } \\
\text { work efficiency } \\
\text { and had high } \\
\text { precision. }\end{array}$ & ૫ & $\begin{array}{l}\text { The bacteriology } \\
\text { examination of } \\
\text { product dispensed } \\
\text { by the dispenser } \\
\text { was satisfactory. }\end{array}$ & 口 & $\begin{array}{l}\text { The dispenser could save } \\
\text { consumables and reduce } \\
\text { costs. }\end{array}$ & - & - \\
\hline $\begin{array}{l}\text { Song L } \\
2019[31]\end{array}$ & प्र & $\begin{array}{l}\text { The automated } \\
\text { compounding } \\
\text { device improved } \\
\text { the working } \\
\text { efficiency and }\end{array}$ & - & - & - & - & - & - \\
\hline
\end{tabular}

Page $11 / 15$ 
reduced the

incidence of errors.

\begin{tabular}{|c|c|c|c|c|c|c|c|c|}
\hline $\begin{array}{l}\text { Shen GR } \\
2017[32]\end{array}$ & [ & $\begin{array}{l}\text { Robots could } \\
\text { complete the main } \\
\text { work in a } \\
\text { informational and } \\
\text { automatic way, } \\
\text { and improve the } \\
\text { level of } \\
\text { management. }\end{array}$ & - & - & - & - & - & - \\
\hline $\begin{array}{l}\text { Lo } \\
2014[33]\end{array}$ & [ & $\begin{array}{l}\text { Automated } \\
\text { dispensing } \\
\text { cabinets were } \\
\text { associated with a } \\
\text { significantly } \\
\text { reduced order-to- } \\
\text { administration } \\
\text { time for first } \\
\text { doses. }\end{array}$ & - & - & - & - & - & - \\
\hline $\begin{array}{l}\text { Ishimoto } \\
2011[34]\end{array}$ & [ & $\begin{array}{l}\text { The automatic } \\
\text { dispenser was } \\
\text { more productive. }\end{array}$ & - & - & [ & $\begin{array}{l}\text { The automatic dispenser } \\
\text { could reduce the number } \\
\text { of pharmacists }\end{array}$ & - & - \\
\hline
\end{tabular}

\section{Non-controlled studies}

$\begin{array}{ll}\text { Jobard } & \square \quad \begin{array}{l}\text { The precision was } \\ \text { validated for all } \\ \text { preparations. }\end{array}\end{array}$

complied with ISO

5 class

environment, but

gloves of

personne

presented

microbiologica

growth.

$\begin{array}{ll}\text { Sabatini }-\quad & \text { The robot met the } \\ \text { 2019[36] } & \text { requirements for } \\ & \text { advanced aseptic } \\ \text { processing in the } & \text { hospital } \\ \text { pharmacies and } & \text { the } \\ & \text { pharmaceutical } \\ \text { industry in } \\ \text { general, providing } \\ \text { advantages in } \\ \text { terms of safety } \\ \text { for patients. }\end{array}$

\begin{tabular}{|c|c|c|c|c|c|c|c|}
\hline $\begin{array}{l}\text { Nurgat } \\
2019[37]\end{array}$ & प & $\begin{array}{l}\text { It is feasible to } \\
\text { replace some of } \\
\text { the manual } \\
\text { compounding of } \\
\text { small-volume } \\
\text { parenteral } \\
\text { preparations } \\
\text { through batch } \\
\text { compounding } \\
\text { using an IV robotic } \\
\text { device. }\end{array}$ & - & & - & ૫] & $\begin{array}{l}\text { Responses } \\
\text { resulted in } \\
\text { the } \\
\text { agreeance } \\
\text { that the } \\
\text { overall } \\
\text { impression } \\
\text { of robot } \\
\text { was "very } \\
\text { good." The } \\
\text { safety } \\
\text { features of } \\
\text { robot had a } \\
\text { median } \\
\text { score of } \\
\text { being "very } \\
\text { safe." }\end{array}$ \\
\hline $\begin{array}{l}\text { Carrez } \\
2018[38]\end{array}$ & प्रा & $\begin{array}{l}\text { The automated } \\
\text { system was able } \\
\text { to produce } \\
\text { chemotherapy } \\
\text { effectively, } \\
\text { delivering } \\
\text { appropriate quality } \\
\text { with productivity. }\end{array}$ & प्रा & $\begin{array}{l}\text { The automated } \\
\text { systems have the } \\
\text { potential to } \\
\text { guarantee optimal } \\
\text { safety for patients } \\
\text { and technicians. }\end{array}$ & - & - & \\
\hline $\begin{array}{l}\text { Krämer } \\
2018[39]\end{array}$ & - & - & प्रा & $\begin{array}{l}\text { The robot } \\
\text { revealed an } \\
\text { adequate level of } \\
\text { sterility and a } \\
\text { well-controlled } \\
\text { aseptic procedure. }\end{array}$ & - & - & - \\
\hline $\begin{array}{l}\text { Zhao Y } \\
2018[40]\end{array}$ & प्रा & $\begin{array}{l}\text { The robot was } \\
\text { safer and more } \\
\text { accurate, and }\end{array}$ & ૫ & $\begin{array}{l}\text { The robot could } \\
\text { provide the } \\
\text { effective }\end{array}$ & - & - & \\
\hline
\end{tabular}

Page 12/15 


\begin{tabular}{|c|c|c|c|c|c|c|c|c|}
\hline & & $\begin{array}{l}\text { improved the } \\
\text { working efficiency } \\
\text { of nurses. }\end{array}$ & & $\begin{array}{l}\text { occupational } \\
\text { protection and } \\
\text { reduce the } \\
\text { incidence of } \\
\text { nosocomial } \\
\text { infection. }\end{array}$ & & & & \\
\hline $\begin{array}{l}\text { Chen } \\
\text { 2013[10] }\end{array}$ & $\mathrm{Qu}$ & $\begin{array}{l}\text { The success rate } \\
\text { rose slowly from } \\
76.8 \% \text { to } 95.3 \% \\
\text { over the 2-month } \\
\text { recording period. } \\
\text { The major } \\
\text { mechanical } \\
\text { problems } \\
\text { encountered were } \\
\text { air, clamping, and } \\
\text { waste bin } \\
\text { problems. }\end{array}$ & - & - & ૫ & $\begin{array}{l}\text { Robot was not able to } \\
\text { improve the FTE } \\
\text { pharmacists/technicians. }\end{array}$ & - & - \\
\hline $\begin{array}{l}\text { Schoening } \\
2016[41]\end{array}$ & 吅 & $\begin{array}{l}\text { The automated } \\
\text { admixing process } \\
\text { of the device } \\
\text { showed } \\
\text { remarkable } \\
\text { effectivity and a } \\
\text { satisfying } \\
\text { accuracy, but the } \\
\text { manual } \\
\text { preprocessing and } \\
\text { postprocessing } \\
\text { steps were time } \\
\text { consuming. }\end{array}$ & 口 & $\begin{array}{l}\text { Validation of the } \\
\text { automated } \\
\text { preparation } \\
\text { process showed } \\
\text { no } \\
\text { microbiological } \\
\text { growth. }\end{array}$ & - & & - & \\
\hline $\begin{array}{l}\text { De La } \\
\text { Ramos } \\
\text { 2015[42] }\end{array}$ & प्रा & $\begin{array}{l}\text { The robot allows } \\
\text { to identify errors, } \\
\text { promoting safety } \\
\text { and quality. }\end{array}$ & - & & - & & - & \\
\hline $\begin{array}{l}\text { Sessink } \\
2014[43]\end{array}$ & - & & प्राप्र & $\begin{array}{l}\text { The robot had low } \\
\text { pollution level, } \\
\text { with the greatest } \\
\text { safety for } \\
\text { technical } \\
\text { personnel. }\end{array}$ & - & & - & \\
\hline $\begin{array}{l}\text { Yaniv } \\
\text { 2013[44] }\end{array}$ & 吅 & $\begin{array}{l}\text { The robot } \\
\text { performed } \\
\text { compounding } \\
\text { tasks safely and } \\
\text { accurately. }\end{array}$ & - & & - & & - & \\
\hline $\begin{array}{l}\text { Cluck } \\
\text { 2012[45] }\end{array}$ & - & & ૫ & $\begin{array}{l}\text { Patients revealed } \\
\text { no positive blood } \\
\text { cultures, and none } \\
\text { of the patients } \\
\text { developed signs } \\
\text { or symptoms of } \\
\text { infection, when } \\
\text { using the robot for } \\
\text { intravenous } \\
\text { medication } \\
\text { preparation. }\end{array}$ & - & & - & \\
\hline \multicolumn{9}{|c|}{ Qualitative Study } \\
\hline $\begin{array}{l}\text { Wang T } \\
2019[46]\end{array}$ & 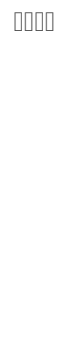 & $\begin{array}{l}\text { Robots have } \\
\text { obvious } \\
\text { advantages, but it } \\
\text { is necessary to } \\
\text { strengthen the } \\
\text { training of using } \\
\text { methods, so that } \\
\text { nurses can master } \\
\text { the operation } \\
\text { methods and } \\
\text { improve the } \\
\text { experience. }\end{array}$ & $\mathrm{Qu}$ & $\begin{array}{l}\text { Robots have } \\
\text { obvious } \\
\text { advantages, but it } \\
\text { is necessary to } \\
\text { strengthen the } \\
\text { training of using } \\
\text { methods, so that } \\
\text { nurses can master } \\
\text { the operation } \\
\text { methods and } \\
\text { improve the } \\
\text { experience. }\end{array}$ & - & & - & \\
\hline \multicolumn{9}{|c|}{ Economic study } \\
\hline $\begin{array}{l}\text { Urbine } \\
\text { 2014[8] }\end{array}$ & - & $\begin{array}{l}\text { The use of a } \\
\text { robotic device can } \\
\text { prevent errors that } \\
\text { can cause adverse } \\
\text { drug events. }\end{array}$ & - & & 吅 & $\begin{array}{l}\text { The use of a robotic } \\
\text { device can reduce health } \\
\text { care costs by preventing } \\
\text { errors that can cause } \\
\text { adverse drug events. }\end{array}$ & & \\
\hline
\end{tabular}

Note: Effectiveness: $\triangle$ Production efficiency $\otimes$ Medicine residues $\triangle$ Preparation accuracy $₫$ Preparation errors 


\section{Figures}

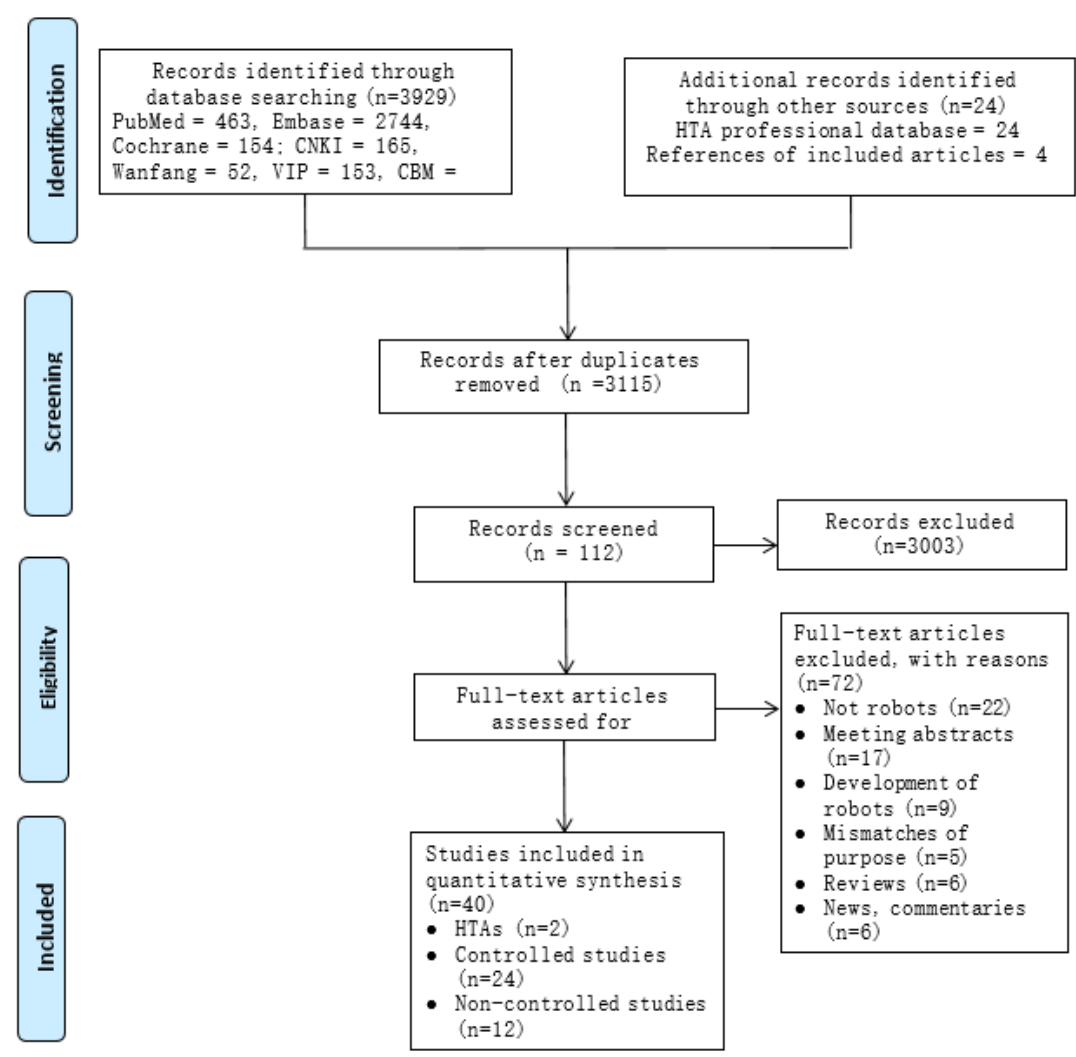

Figure 1

Literature inclusion process and results

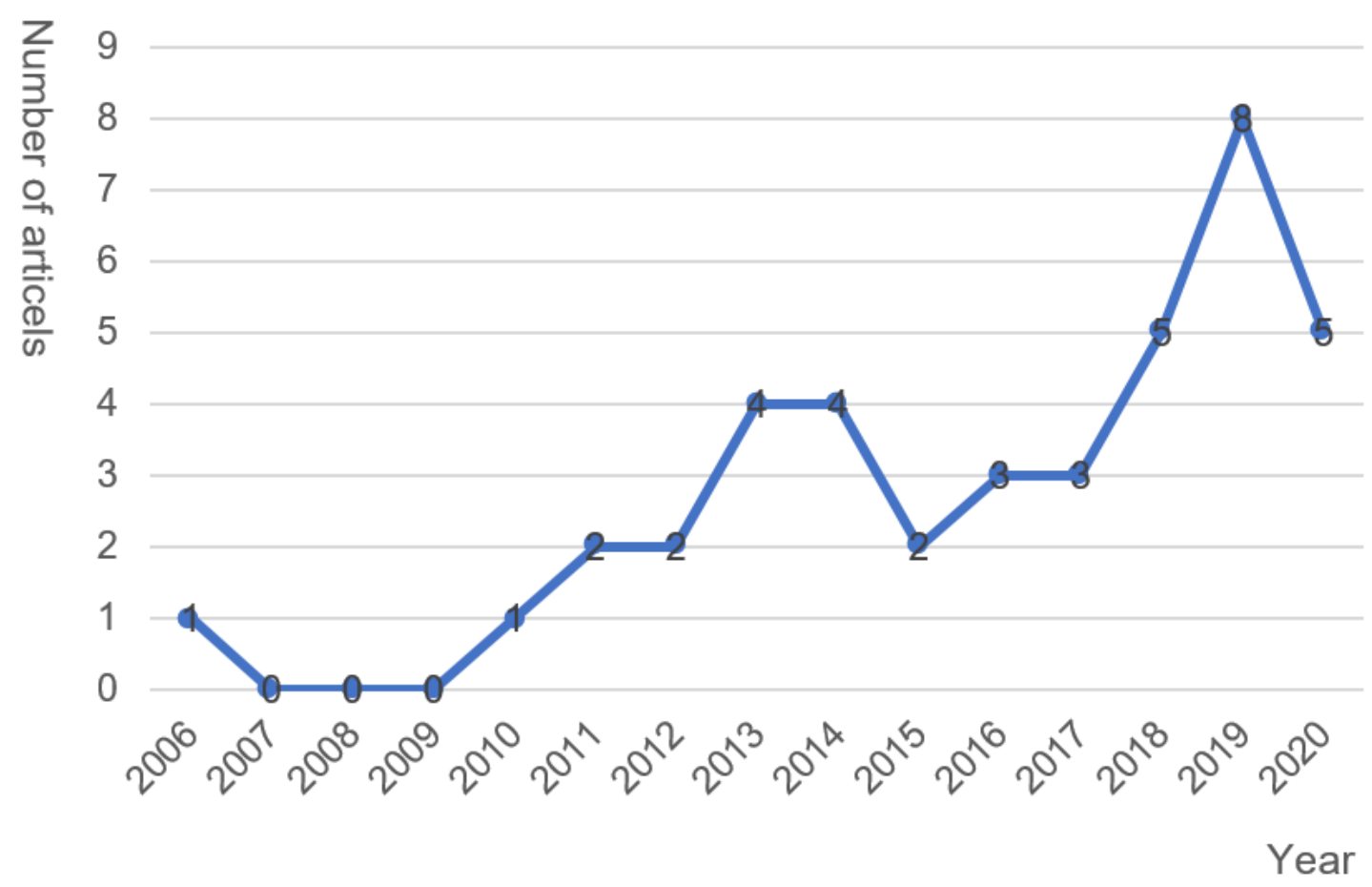


Figure 2

bibliometric analysis of articles on intravenous compounding robots

\section{Supplementary Files}

This is a list of supplementary files associated with this preprint. Click to download.

- Appendix1Searchstrategyandresultsofsearching.docx

- Appendix2Resultsofqualityassessments.docx

- PRISMA2009checklist.doc 